\title{
Pit and fissure depth in the enamel of mandibular third molars: An open gate for microleakage?
}

\author{
Osvaldo Zmener' ${ }^{1}$, Cornelis H. Pameijer², Ana C. Boetto ${ }^{3}$, Mariana Picca ${ }^{4}$ \\ 1. Universidad del Salvador, Facultad de Ciencias Médicas, Escuela de Odontología, Buenos Aires, Argentina \\ 2. University of Connecticut, School of Dental Medicine, Department of Reconstructive Sciences, Farmington, USA \\ 3. Universidad de Córdoba, Facultad de Odontología, Cátedra de Endodoncia, Córdoba, Argentina \\ 4. Universidad de Buenos Aires, Facultad de Odontología, Cátedra de Materiales Dentales, Buenos Aires, Argentina
}

\begin{abstract}
The aim of this descriptive ex vivo study was to evaluate qualitatively the depth of pit and fissures $(P \& F)$ of the enamel in human mandibular third molars. Fifty $(n=50)$ extracted human mandibular third molars were cleaned and disinfected. All tooth surfaces were coated with nail varnish except for a 1-mm margin around the periphery of the occlusal surface. The teeth were immersed for 48 hours at $37{ }^{\circ} \mathrm{C}$ in $1 \%$ methylene blue dye solution prepared in artificial saliva. After cleaning, the crowns were separated from the root at the cementoenamel junction and subsequently sectioned longitudinally in buccolingual direction at the location of the central fossa. All sections were examined using a stereoscopic microscope and photographed. The images were downloaded on a computer. The length of penetration of the $P \& F$ was recorded using the following scoring system: $C 1: P \& F$ extended to half of the enamel thickness; $C 2: P \& F$ extended beyond half of the enamel
\end{abstract}

thickness without reaching the dentine-enamel junction; C3: $P \& F$ extended to the dentine-enamel junction. For pits, $C 1, C 2$ and $C 3$ were observed in 35, 9 and 6 teeth, respectively, while for fissures, C1, C2 and C3 were observed in 15, 18 and 17 teeth, respectively. The $P \& F$ detected in the samples extended to the deepest portions of enamel, quite frequently reaching the enamel-dentine junction. Clinicians should recognize that even if pits and fissures are not clinically obvious, they penetrate deep into the enamel and frequently reach the dentine-enamel junction. Effective treatment is recommended to block access to $P \& F$, thus preventing ingress of bacteria.

Received: March 2021: Accepted: July 2021.

Keywords: dental enamel - dentine - molar - pit and fissures sealants.

\section{Profundidad de fosas y fisuras en el esmalte de terceros molares inferiores ¿Una puerta abierta a la microfiltración?}

\begin{abstract}
RESUMEN
Objetivos: El objetivo del presente estudio descriptivo fue evaluar cualitativamente mediante un ensayo ex vivo la profundidad de las fosas y fisuras $(F \& F)$ del esmalte en terceros molares inferiores humanos. Materiales y métodos: Cincuenta $(n=50)$ terceros molares inferiores sanos extraídos se lavaron, se descontaminaron y se recubrieron con esmalte para uñas hasta $1 \mathrm{~mm}$ menos del área de las $F \& F$. Luego se sumergieron durante 48 horas a $37^{\circ} \mathrm{C}$ en una solución de azul de metileno al $1 \%(\mathrm{pH}$ $7,4)$ preparada con saliva artificial. Posteriormente se lavaron y se separaron las coronas a nivel del limite amelocementario. En cada molar se realizó una sección longitudinal de $1 \mathrm{~mm}$ de espesor con orientación vestíbulo-lingual a nivel de la fosa central. Las secciones fueron analizadas con microscopio estereoscópico y fotografiadas. Las imágenes se transfirieron a una computadora. Se determinó cualitativamente la extensión
\end{abstract}

de las F\&F en el espesor del esmalte y se las clasificó de acuerdo a 3 categorías. C1: extensión hasta la mitad del espesor del esmalte; C2: extensión que supera la mitad del espesor del esmalte sin afectar el límite amelodentinario; C3: extensión que llega al limite amelodentinario. Resultados: Para las fosas, 35, 9 y 6 especimenes correspondieron a las categorías $C 1, C 2$ y $C 3$ respectivamente. Para las fisuras, 15,18 y 17 especimenes correspondieron a las categorías C1, C2 y C3 respectivamente. Conclusiones: Las fosas y fisuras de la muestra analizada se extienden hasta la zona más profunda del espesor del esmalte. Con cierta frecuencia llegan hasta el límite amelodentinario.

Palabras clave: dentina - esmalte dental - molar - selladores de fosas y fisuras. 


\section{INTRODUCTION}

Pits and fissures (P\&F) of enamel surfaces in deciduous and permanent teeth are susceptible areas in which biofilm, food and bacterial debris can accumulate, leading to the development of acid-producing plaque resulting in caries ${ }^{1}$. The carbohydrates from food will be broken down, leading to demineralization of enamel. The extent of $\mathrm{P} \& \mathrm{~F}$ is difficult to measure during a clinical examination. There are many investigations reporting different protocols for cleaning $\mathrm{P} \& \mathrm{~F}^{2}$ and for sealant application ${ }^{3-5}$.

In a study published in 2007, Cruvivnel et $\mathrm{al}^{6}$ suggested that the depth of $\mathrm{P} \& \mathrm{~F}$ is the most critical factor in terms of possible pulpal involvement. They showed that in the permanent dentition, the deepest part of the P\&F is frequently located near or in direct contact with the enamel-dentine junction. They also hypothesized that in these cases, resident bacteria may leak into the pulp via dentinal tubules, which in turn may explain why some patients may complain of pain in "clinically healthy molars"7-9. The literature related to P\&F depth and caries incidence in permanent molars is scarce ${ }^{10}$. The aim of this descriptive ex vivo assay was to evaluate qualitatively the depth of penetration of $P \& F$ in the enamel of human permanent third molars. The null hypothesis tested was that the enamel-dentine junction is not compromised by the depth of the P\&F.

\section{MATERIALS AND METHODS}

The experimental protocol of the present study was authorized by the Institutional Research Ethics Committee of the Argentine Dental Association (Approval Code \# 2019/0118-AOA). For this study, fifty $(\mathrm{n}=50)$ extracted human third molars stored at $4{ }^{\circ} \mathrm{C}$ in $2 \%$ thymol in normal saline were used. Inclusion criteria were being free of caries, restorations, pigmentations or other morphological alterations of the enamel, and having a centralized P\&F system on the occlusal surface with at least one central fossa. The absence of clinically undetectable caries was confirmed with a laser fluorescence device (Diagnodent; Kavo, Biberach, Germany) as described by Lussi et al ${ }^{9}$.

After removal of gross debris attached to the roots, the occlusal surface of each tooth was cleaned for 30 seconds with a pumice/water slurry in a rubber cup at low-speed. The samples were then rinsed for 20 seconds with an air-water spray and dried with oil- free compressed air for another 20 seconds. After the root apexes were sealed with cyanoacrylate (Cyano Anaeróbicos, Buenos Aires, Argentina), the teeth were totally covered with two layers of nail varnish except for a 1-mm peripheral margin on the occlusal P\&F. The teeth were then immersed in 1\% buffered methylene blue dye solution prepared in artificial saliva (Salivar; Farpag Ltda, Buenos Aires, Argentina) and stored at $37{ }^{\circ} \mathrm{C}$. After 48 hours, the teeth were removed from the dye solution, rinsed in tap water and dried. The crowns were separated from the roots at the cementoenamel junction using a diamond disc. The crowns were then embedded in methyl methacrylate resin and sectioned longitudinally on a buccolingual plane using a diamond wavering blade under watercooling (Isomet, Buehler Ltd, Lake Bluff, IL, USA). A longitudinal section $1 \mathrm{~mm}$ thick was obtained at the location of the central fossa.

\section{Evaluation of the sections}

After drying with oil-free compressed air, the sections were examined under x14 magnification with stereomicroscope (Carl Zeiss, Oberkochen, Germany) and photographed with a digital Canon Powershot A510 camera (Canon, Tokyo, Japan). Only the side that represented the central fossa was analyzed. The images were downloaded on a computer to enable the length of the P\&F to be measured and graded according to the following grading system: $\mathrm{C} 1: \mathrm{P} \& \mathrm{~F}$ extended to half of the enamel thickness; C2: P\&F extended beyond half of the enamel thickness without reaching the dentineenamel junction; C3: P\&F extended to the enameldentine junction. When a section had more than one $\mathrm{P} \& \mathrm{~F}$, the deepest one was recorded. The images were examined by two independent observers. In case of disagreement, the samples were reexamined jointly until a consensus was reached. The relative frequencies within each group (expressed in percentages) and their corresponding confidence intervals $(95 \%)$ were then calculated.

\section{RESULTS}

All sections revealed the presence of at least one P\&F. Descriptive data for P\&F classification and frequency along with their confidence intervals are reported in Tables 1 and 2. For pits, 35 and 9 samples corresponded to $\mathrm{C} 1$ and $\mathrm{C} 2$, respectively 


\begin{tabular}{|c|c|c|c|c|}
\hline \multirow{2}{*}{ CATEGORY } & \multirow{2}{*}{$\mathbf{n}$} & \multirow{2}{*}{$\%$} & \multicolumn{2}{|c|}{ 95\% CONFIDENCE INTERVAL } \\
\hline & & & LOWER LIMIT & UPPER LIMIT \\
\hline C1 & 35 & 70.0 & 57.0 & 83.0 \\
\hline C2 & 9 & 18.0 & 7.1 & 28.9 \\
\hline C3 & 6 & 12.0 & 2.8 & 21.2 \\
\hline
\end{tabular}

(Fig. $1 \mathrm{~A}$ and B). Six were considered to be in the $\mathrm{C} 3$ category (Fig. $1 \mathrm{C}$ ). In four of them, incipient traces of dentine dye penetration were observed (Fig.1 D). For fissures, 15 samples corresponded to $\mathrm{C} 1,18$ to $\mathrm{C} 2$ (Fig.1 E) and 17 to $\mathrm{C} 3$. All samples rated C3

\begin{tabular}{|c|c|c|c|c|}
\hline \multirow{2}{*}{ CATEGORY } & \multirow{2}{*}{$\mathbf{n}$} & \multirow{2}{*}{$\%$} & \multicolumn{2}{|c|}{ 95\% CONFIDENCE INTERVAL } \\
\hline & & & LOWER LIMIT & UPPER LIMIT \\
\hline C1 & 15 & 30.0 & 17.0 & 43.0 \\
\hline C2 & 18 & 36.0 & 22.4 & 49.6 \\
\hline C3 & 17 & 34.0 & 20.5 & 47.5 \\
\hline
\end{tabular}

revealed traces of dentine dye penetration (Fig.1 $F$ and $G$ ). Based on the 50 studied P\&F sections, the enamel-dentine junction was affected in $12 \%$ of pits and $34 \%$ of fissure samples. Therefore, the null hypothesis was rejected.
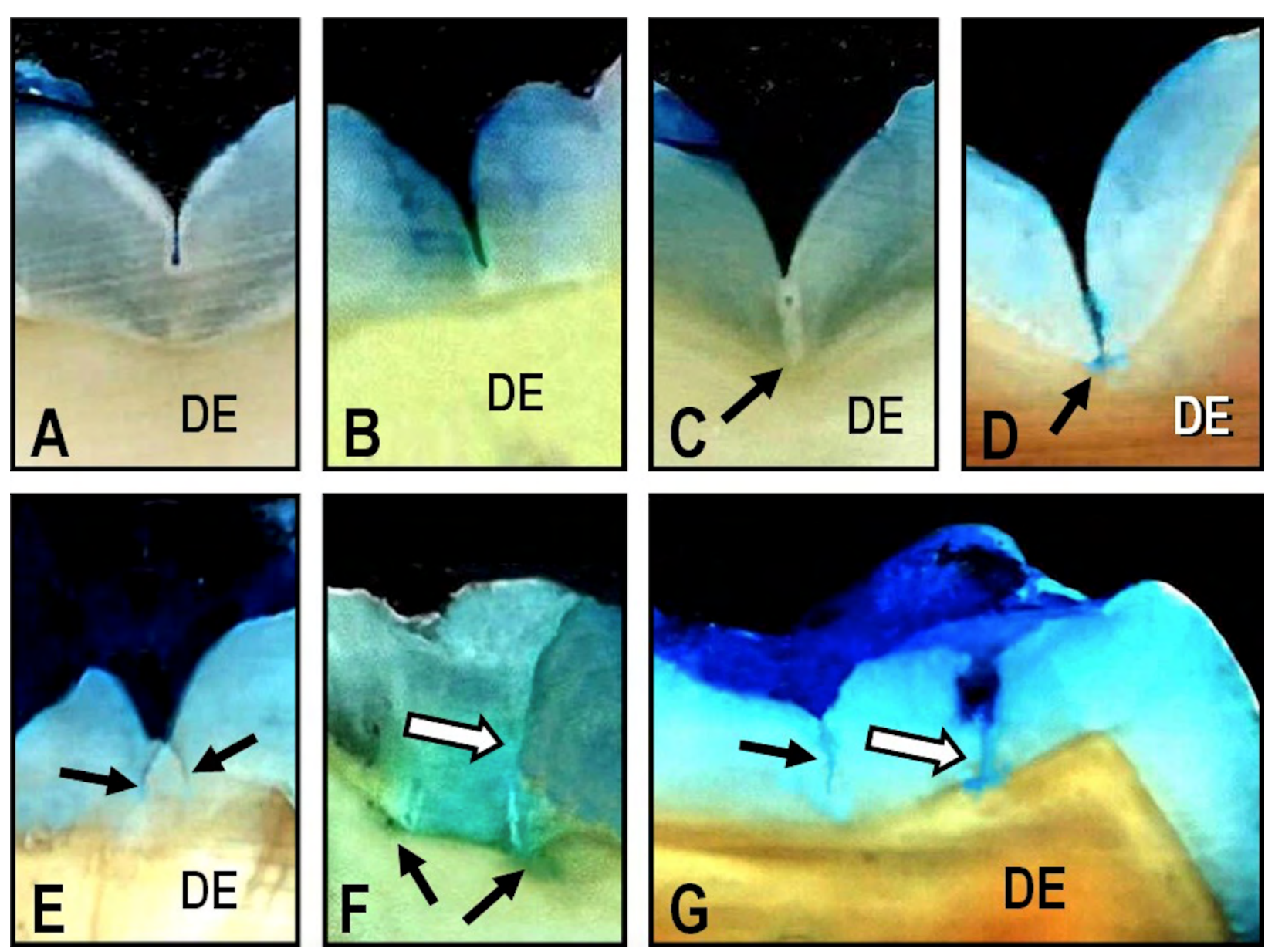

Fig. 1: A. Photomicrograph of representative pit formation corresponding to C1. DE: Dentine; Original magnification x14. B. Photomicrograph of representative pit formation corresponding to $C 2$. Note that the pit extension does not reach the enamel-dentine junction. DE: Dentine; Original magnification x14. C: Photomicrograph of representative C3 pit formation reaching the enamel-dentine junction (arrow). DE: Dentine; Original magnification x14. D. Photomicrograph of representative pit formation corresponding to C3 showing incipient dentine dye penetration (arrow). DE: Dentine; Original magnification x14. E. Photomicrograph showing two fissure formations corresponding to C2 (arrows). Note that both fissures started at the deepest part of a pit formation DE: Dentine; Original magnification x14. F. Photomicrograph of representative fissure formation (white arrow) corresponding to C3. Note the presence of dye penetration into dentine and along the enamel-dentine junction (black arrows). Original magnification x14. G. Photomicrograph of two fissures corresponding to C2 (black arrow) and C3 (white arrow). Note the incipient dye penetration along the dentine-enamel junction. DE: Dentine; Original magnification x14. 


\section{DISCUSSION}

The present study aimed to mimic some of the in vivo conditions in which the enamel is permanently challenged by the oral environment. For this study, the samples were exposed to a methylene blue dye solution prepared in artificial saliva which contained potassium, magnesium and calcium electrolytes, though without bacteria, unlike intra-oral saliva. In order to estimate the frequency and depth of $\mathrm{P} \& \mathrm{~F}$, the methylene blue dye solution was used as the marker. In previous ex vivo studies ${ }^{1-4}$, dye leakage was used as a predictor of bacterial penetration. However, its correlation with clinical implications should be interpreted with caution and still requires further research. The results of this ex vivo study showed that the enamel-dentine junction was affected in less than $50 \%(46 / 50)$ of the study samples. From an epidemiologic point of view, this proportion of $\mathrm{P} \& \mathrm{~F}$ that reached the enamel-dentine junction is a suitable indicator of the risk of developing dental caries. Thus, we may speculate that in cases of $\mathrm{C} 3$ categories, penetration of bacteria into dentinal tubules may occur, leading to further access to the pulpal chamber ${ }^{7,8}$.

Due to the presence of fermentable carbohydrates and bacterial by-products in the dentinal tubules, inflammatory pulp reactions causing pain are frequently reported by patients ${ }^{7}$. Björndal and $\mathrm{Mjör}^{8}$ emphasized that the internal morphology of the interlobar grooves, as well as the potential depth of $\mathrm{P} \& \mathrm{~F}$, are important factors to consider during

\section{ACKNOWLEDGMENTS}

The authors are grateful to Dr. Susana Alvarez Serrano and Dr. Fanny Fernandez for their technical assistance.

\section{DECLARATION OF CONFLICTING INTERESTS}

The authors declare no potential conflicts of interest regarding the research, authorship, and/or publication of this article. clinical examination. However, Ricketts et $\mathrm{al}^{11}$ reported on the difficulty to detect enamel alterations or incipient caries formation in the deepest part of the P\&F because the morphology of enamel does not always follow a normal pattern ${ }^{12,13}$.

Our results are in agreement with previous reports ${ }^{10,14}$ which suggest that every effort should be made to ensure early detection of decalcified areas ${ }^{14-16}$, which is a consequence of cariogenic onset due to active acid-producing plaque at the base of P\&F. Careful examination of the occlusal anatomy will enable the clinician to select the most effective treatment for $\mathrm{P} \& \mathrm{~F}^{4,17-20}$ and make the decision to restore with a filling or apply a P\&F sealant. Unprotected (unsealed) P\&F can act as an open gate for the entry of bacteria and other irritants from the oral environment. However, since this study was performed under ex vivo conditions, its clinical relevance needs to be interpreted with caution.

\section{CONCLUSION}

Within the limitations of the present study, we conclude that in human mandibular third molars, the $\mathrm{P} \& \mathrm{~F}$ frequently reach the dentin-enamel junction. When this is the case, there is a potential open gate for bacteria and other irritants from the oral environment to penetrate the dentinal tubules, thereby enabling bacteria and bacterial toxins to reach the dental pulp. This may explain the clinical symptoms reported by patients in otherwise healthy teeth.

\section{FUNDING}

None.

\section{CORRESPONDENCE}

Dr. Osvaldo Zmener

Julian Alvarez 23353 ro.

(1425), Ciudad Autónoma de Buenos Aires

Argentina

osvaldo@zmener.com.ar

\section{REFERENCES}

1. Gillet D, Nancy J, Dupuis V, Dorignac G. Microleakage and penetration depth of three types of materials in fissure sealant: self-etching primer vs etching: an in vitro study, J Clin Pediatr Dent 2002; 26:175-178.

2. Chan DCN, Summitt JB, García-Godoy F, Hilton T et al. Evaluation of different methods for cleaning and preparing occlusal fissures. Oper Dent 1999;24: 331-336.

3. Pardi V, Sinhoreti MAC, Pereira AC, Ambrosano GMB et al. In vitro evaluation of microleakage of different materials used as pit-and-fissure sealants. Braz Dent J 2006;17: 4952.

4. Asselin ME, Fortin D, Sitbon Y, Rompré PH. Marginal microleakage of a sealant applied to permanent enamel: Evaluation of 3 application protocols. Pediatr Dent 2008;30: 29-33.

5. Markovic DL, Petrovick BB, Peric TO, Trisic D et al. 
Evaluation of sealant penetration in relation to fissure morphology, enamel surface preparation protocol and sealing material. Oral Health Prev Dent 2019;17:349-355.

6. Cruvivnel VRN, Azevedo BC, Gravina DBL, Toledo et al. Clinical analysis of molar fissures by Cone-Beam Tomography. J Clin Pediatr Dent 2007;31:235-239.

7. Zero DT, Ferreira-Zandona A, Vail MM, Spolnik KJ. Dental caries and pulpal disease. Dent Clin North Am 2011;55: 2946.

8. Björndal L, Mjör A. Pulp-dentin biology in restorative dentistry. 4. Dental caries - characteristics of lesions and pulpal reactions. Quintess Int 2001; 32:717-736.

9. Lussi A, Imwinkelried S, Pitts N, Longbottom C et al. Perfomance and reproducibility of a laser fluorescence system for detection of occlusal caries in vitro. Caries Res 1999;33:261-266.

10. Sanchez-Perez L, Irigoyen-Camacho ME, MolinaFrechero N, Zepeda-Zepeda M. Fissure depth and caries incidence in first permanent molars: A five-year follow-up study in schoolchildren. Int J Environ Res Public Health 2019;16:3550-3560.

11. Ricketts D, Kidd D, Weerheijm K, De Soet H. Hidden caries: What is it? Does it exist? Does it matter? Int Dent J 1997;47:259-265.

12. Lussi A. Validity of diagnostic and treatment decisions of fissure caries. Caries Res 1991;25:296-303.

13. Symons AL, Chu CY, Meyers IA. The effect of fissure morphology and pretreatment of the enamel surface on penetration and adhesion of fissure sealants, J Oral Rehabil 1996;23:791-798.

14. Ando M, van Der Veen MH, Schemehorn BR, Stookey GK. Comparative Study to quantify demineralized enamel in deciduous and permanent teeth using laser - and light induced fluorescence techniques. Caries Res 2001;35:464-470.

15. Ferreira-Zandona A, Zero D. Diagnostic tools for early caries detection. J Am Dent Assoc 2006; 137: 1675-1684. Erratum in: J Am Dent Assoc 2007;138:298.

16. Shi X, V. Welander V. Occlusal caries detection with Kavo Diagnodent and radiography. An in vitro comparison. Caries Res 2000;34:51-158.

17. Peumans M, Canumilli P, De Munk J, Van Landuyt K et al. Clinical effectiveness of contemporary adhesives: A sistematic review of current clinical trials. Dent Mater 2005; 21:864-881.

18. Sakkas C, Khomenko L, Trachuk I. A comparative study of clinical effectiveness of fissure sealing with and without bonding systems: 3-year results. Eur Arch Pediatr Dent 2013; 14:73-81.

19. Meller C, Reichenmiller K, Schwahn C, Samietz S et al. Resin- based pit-and-fissure sealants: Microleakage reduction and infiltration enhancement using a bonding agent. J Adhes Dent 2015;17:59-65.

20. Al-Jobair A, Al-Hammad N, Aladhan S, Salama F. Retention and caries-preventive effects of glass ionomer and resinbased sealants: An 18-months-randomized clinical trial. Dent Mater J 2017;36:654-661. 